\title{
5G in India
}

\author{
Deepak Kumar Ray ${ }^{[1]}$, Shruti K. Oza ${ }^{[2]}$, Rajat Sharma ${ }^{[3]}$, Akhil Anand ${ }^{[3]}$, Abhishek Kumar ${ }^{[3]}$ \\ ${ }^{[1]}$ Assistant Professor of Electronics and Telecommunication Department \\ ${ }^{[2]}$ Head of Department of Electronics and Telecommunication \\ ${ }^{[3]}$ Students of Electronics and Telecommunication Department \\ Bharati Vidyapeeth (Deemed to be)University College Of Engineering \\ Dhankawadi, Pune, India 411043
}

\begin{abstract}
G (Fifth generation) stands for the next major phase of mobile telecommunications standards beyond the current 4G/IMT-Advanced standards. As the expectation of the public increases with the advancement of the technology comes into picture, the services that can be obtained using the telecom networks have widened. Applications such as High-speed internet, Internet of Things, critical communications etc. the telecom network needs to support high data rate, low latency, reliability etc.

5G has speeds further what the present $4 G$ can provide. From generation 1G to $2.5 \mathrm{G}$ and from $3 \mathrm{G}$ to $5 \mathrm{G}$ this world of telecommunication has seen a number of advancement along with improved performance with every passing day from IMT 2020, there are several requirements from the users and network side, which has to be supported in 5G to support the use cases. To fulfill the requirement, several technologies are being considered in 5G.
\end{abstract}

\section{Key Words: 5G, Advancement, Requirement, Latency}

\section{INTRODUCTION}

After every 10 years, new mobile generation has come since the first $1 \mathrm{G}$ (generation) system which came in 1982. After 10 years, the next generation which was introduced is $2 \mathrm{G}$ in 1992 and the first $3 \mathrm{G}$ system introduced in 2001. 4G system was introduced in 2012. The development of GSM that is $2 \mathrm{G}$ and CDMA i.e. $3 \mathrm{G}$ were officially done about 10 year after all the $\mathrm{R} \& \mathrm{D}$ projects where done.

We have observed remarkable growth of cellular communication over the radio. With ever- increasing subscriber base and limited radio resource, providing quality telecom services became difficult. These issues led mobile service providers to research into technologies and improve the quality of service and be able to support more users in their systems. Wireless communication networks have become much more pervasive than anyone could have imagined when the cellular concept was first deployed in 1960's and 1970's. Mobile cellular subscribers are increasing by more than $40 \%$ per year. Therefore Cellular communication has been continuously evolving into newer forms.Radio technologies have evidenced a rapid and multidirectional evolution with the launch of the analogue cellular systems in 1980s.

[1] Thereafter, digital wireless communication systems are consistently on a mission to fulfill the growing need of human beings ( $1 \mathrm{G}$ to $4 \mathrm{G}$, or now $5 \mathrm{G}$ ).
1G: $1 \mathrm{G}$ is the 1 st generation. It is simply used to make phone calls; this is all it was able to do.

2G: The second generation provided customers with the facility of voice calling and text messaging. $2 \mathrm{G}$ networks are digital.

3G: This technology sets the standard for most of the wireless networks. Third generation allowed the use of internet on the mobile phone, while also enabling picture-sharing and Bluetooth Connectivity.

4G: It offers first true internet broadband data transmission rates. Its data transmission rates are 10 times faster than $3 \mathrm{G}$ technology.

5G: $5 \mathrm{G}$ will be the network for millions of devices and not just for the smart phone. It promises to enable fast (and secure) connectivity between devices other than smart phones, such as sensors, vehicles, robots, and drones. It will have data speed up to 1 to $10 \mathrm{Gbps}$. [1]

\begin{tabular}{|l|l|l|l|}
\hline S.N & $\begin{array}{l}\text { Mobile Technology } \\
\text { in India }\end{array}$ & $\begin{array}{l}\text { Frequency } \\
\text { bands in India }\end{array}$ & Operators \\
\hline 1 & GSM(2G) & $\begin{array}{l}900 \mathrm{MHz}, 1800 \\
\mathrm{MHz}\end{array}$ & $\begin{array}{l}\text { Airtel, Idea- } \\
\text { Vodafone, BSNL }\end{array}$ \\
\hline 2 & CDMA & $850 \mathrm{MHz}$ & $\begin{array}{l}\text { Reliance, BSNL, } \\
\text { Tata }\end{array}$ \\
\hline 3 & WCDMA(3G) & $\begin{array}{l}2100 \mathrm{MHz}, 900 \\
\mathrm{MHz}\end{array}$ & $\begin{array}{l}\text { Airtel, Idea- } \\
\text { Vodafone }\end{array}$ \\
\hline 4 & WiMAX & $2300 \mathrm{MHz}$ & BSNL \\
\hline 5 & $4 \mathrm{G} \mathrm{LTE}$ & $1800 \mathrm{MHz}$ & $\begin{array}{l}\text { Airtel, Idea- } \\
\text { Vodafone, Jio }\end{array}$ \\
\hline & & $850 \mathrm{MHz}$ & Jio \\
\hline & & $2300 \mathrm{MHz}$ & $\begin{array}{l}\text { Airtel, Idea- } \\
\text { Vodafone, Jio }\end{array}$ \\
\hline & & $2500 \mathrm{MHz}$ & $\begin{array}{l}\text { BSNL, Idea- } \\
\text { Vodafone }\end{array}$ \\
\hline
\end{tabular}

Figure 1: Different frequency bands in India

\begin{tabular}{|l|l|}
\multicolumn{2}{|c|}{ 5G SPECIFICATIONS } \\
\hline PARAMETER & SUGGESTED PERFORMANCE \\
\hline 1. Network capacity & $\begin{array}{l}10,000 \text { times capacity of current } \\
\text { network. }\end{array}$ \\
\hline 2. Peak data rate & $10 \mathrm{Gbps}$ \\
\hline 3. Cell edge data rate & $100 \mathrm{Mbps}$ \\
\hline 4. latency & $<1 \mathrm{~ms}$ \\
\hline
\end{tabular}

Table 2: 5G wireless performances 
- $1-10 \mathrm{Gbps}$ connections to deadline points in the field (i.e. not theoretical maximum)

- 1 millisecond end-to-end round trip delay - latency

- $1000 \mathrm{x}$ bandwidth per unit area

- 10-100 x number of connected devices

- Perception of) $99.999 \%$ availability

- Perception of $100 \%$ coverage

- $\quad 90 \%$ decrease in network energy usage

Why spectrum for $5 G$ not purchased in India yet?

Due to extremely high price and several other factors, there is a delay to implement $5 \mathrm{G}$ in India which is the reason why spectrum for $5 \mathrm{G}$ is not yet purchased in India. With price of Rs 492 crore for $1 \mathrm{MHz}$, operators figured out that it is not a viable proposition, keeping the debt and international prices in mind. The Telecom Regulatory Authority of India (TRAI) marked the spectrum in 3,400-3,600 $\mathrm{MHz}$ band for $5 \mathrm{G}$, and suggested that the radio waves will be allocated in blocks of $20 \mathrm{MHz}$. Therefore, to purchase $100 \mathrm{MHz}$ of airwaves, an operator will be supposed to pay around Rs 50,000 crore. The telecom industry is loaded with a compound debt of Rs 7.5 lakh crore and is also undergoing a financial pressure due to the competition with Jio, the only telecom company earning profits. [2] The remaining two private companies- Airtel and Vodafone Idea- are also facing the combined Adjusted Gross Revenue (AGR) dues of around Rs 89,000 crore which they are suppose to pay in less than three months. Hence, it is currently too much problematic for the telecom industry to purchase $5 \mathrm{G}$ spectrum.

\section{$5 G$ in India Vs World}

$5 \mathrm{G}$ require completely new infrastructure in India, that is setting new transmission lines, etc which required high cost. On the other side the developed country like America is progressing their $5 \mathrm{G}$ infrastructure by using space cloning, Which gives low infrastructure cost and high efficiency. In India $5 \mathrm{~g}$ is taking time because of high spectrum cost, expensive infrastructure for transmission of $5 \mathrm{~g}$ signal.

The Department of Telecommunications (DoT) has identified $35 \mathrm{MHz}$ of spectrum in the $700 \mathrm{MHz}$ frequency band, and 300 $\mathrm{MHz}$ of spectrum in the midrange band of $3.3 \mathrm{GHz}$ to $3.6 \mathrm{GHz}$. However, of the $35 \mathrm{MHz}$ of spectrum in the low-frequency (sub-1GHz) band, Indian Railways has demanded $10 \mathrm{MHz}$, leaving only $25 \mathrm{MHZ}$ for telecom operators. [3] Even the 300 $\mathrm{MHz}$ of spectrum from the midrange band is not completely available for telecom operator in this band, the space and defense departments have staked claim to $25 \mathrm{MHZ}$ and 100 $\mathrm{MHz}$ units, respectively, leaving only $175 \mathrm{MHz}$ of spectrum for telecom operators, which will result into high congestion of signal between multiple users.

\section{Challenges to $5 G$ technology in India}

First of all huge investment is required for setting 5G in India. High spectrum cost due to which many telecom operator are not willing to upgrade from $4 \mathrm{G}$ to $5 \mathrm{G}$. High debts of telecom operator which is not clear till now according to survey Airtel has to pay 50000 crore rupees, Idea and Vodafone has to pay 40000 and Jio has to pay 25 crore.
Lack of innovation in India: $5 \mathrm{G}$ plays major role in IOT that's why many companies is eager towards $5 \mathrm{G}$ but due to lack of innovation in India the company or organization is not interested in developing 5G. [4]

Security is also a major issue in $5 \mathrm{G}$. The frequency of $5 \mathrm{G}$ might be harmful for humans and animals, so this is also a challenge for implementing $5 \mathrm{G}$ technology.

\section{Is Current Infrastructure sufficient for $5 G$ in India?}

There are more than 13,000 smart phone model available in India but only 50-60 high end smart phone is $5 \mathrm{G}$ compatible which is also of high cost. $5 \mathrm{G}$ required more than $2,50,000$ cell tower which will be small in size and mounted on traffic signals , lamppost ,rooftop. The traditional tower can also be used in $5 \mathrm{~g}$ but with certain improvement so that it will be compatible with $5 \mathrm{G}$ spectrum. [5]

\section{Issues to be overcome before $5 G$ Implementation}

- Hoaxing and Jamming hoaxing: Hoaxing and Jamming Hoaxing is a fake GPS signal that is been sent out, in which the GPS receiver consider that the signals arrive from the satellites and computes the wrong coordinates. Such wrong computations can lead to more criminal activities and increase the crime rate. Jamming occurs when a transmitter sending out signals at the same frequency shifts a GPS signal.

- Encryption of data: If a GPS receiver will communicate with the main transmitter then the communication link between those two is easy to break and the consumer may use the encrypted data.

- Interception of private communications.

- There is more likely to be security issue such as stealing bank account, stealing private data

- Phishing attacks, stealing bank account details and other secured information, are more likely.

- Since all the network operators and service providers would share a common core network infrastructure, compromise of a single operator will lead to the collapse of the entire network infrastructure, if not carefully guided.

\section{Expected Environmental issues due to $5 G$}

The environmental issues in $5 \mathrm{G}$ arises due to frequency range that is between $30 \mathrm{GHZ}$ to $300 \mathrm{GHZ}$ at which $5 \mathrm{G}$ is supposed to work. EMF studies and published their results in peerreviewed journals that show adverse biological and health effects caused through EMF sources developed by humans. We can organize types of radiation by their levels of power on the electromagnetic spectrum. Bigger wavelengths with lower frequency are less powerful, while smaller wavelengths at higher frequencies are more powerful. This spectrum is divided into two distinct categories: ionizing and nonionizing. Ionizing, which includes ultraviolet rays, X-rays and gamma rays, are the harmful forms. [6] The energy from ionizing radiation can pull apart atoms, and it's known to break the chemical bonds in DNA, which can damage cells and cause cancer. This is why the FDA warns against having unnecessary X-rays. It's also why exposure to the sun can cause skin cancer. 


\section{India Vs China on $5 G$}

Countries such as Australia, New Zealand, Japan and Taiwan besides the US are keeping Huawei out of 5G deployments, while others including France, the Netherlands, Russia and South Korea have allowed the Chinese equipment maker to participate. Major global equipment vendors in India include European companies Ericsson and Nokia, China's Huawei and ZTE and South Korea's Samsung. Vodafone Idea has applied to partner with Ericsson and Huawei for $5 \mathrm{G}$ trials, while Bharti Airtel has sought permission to conduct trials with Nokia, Huawei and Ericsson. Rival Reliance Jio Infocomm has applied for a pilot initiative with Samsung. [7] Vodafone Idea has applied to partner with Ericsson and Huawei for $5 \mathrm{G}$ trials, while Bharti Airtel has sought permission to conduct trials with Nokia, Huawei and Ericsson. Rival Reliance Jio Infocomm has applied for a pilot initiative with Samsung. India is now in dilemma whether $5 \mathrm{~g}$ is to be used or not, but china is doing belt road initiative where it provides infrastructure development $(5 \mathrm{~g}$ is more focused) and investment in more than 70 Asian countries. Due to BRI India is taking service from china based company like Huwaei and Zte. In India idea and Vodafone is against $5 \mathrm{G}$ they are saying that it is better to improve $\$ g$ because $\$ g$ has many functionality similar to $5 \mathrm{G}$ and instead of focusing on $\% \mathrm{~g}$ these companies are doing modification in $4 \mathrm{G}$.

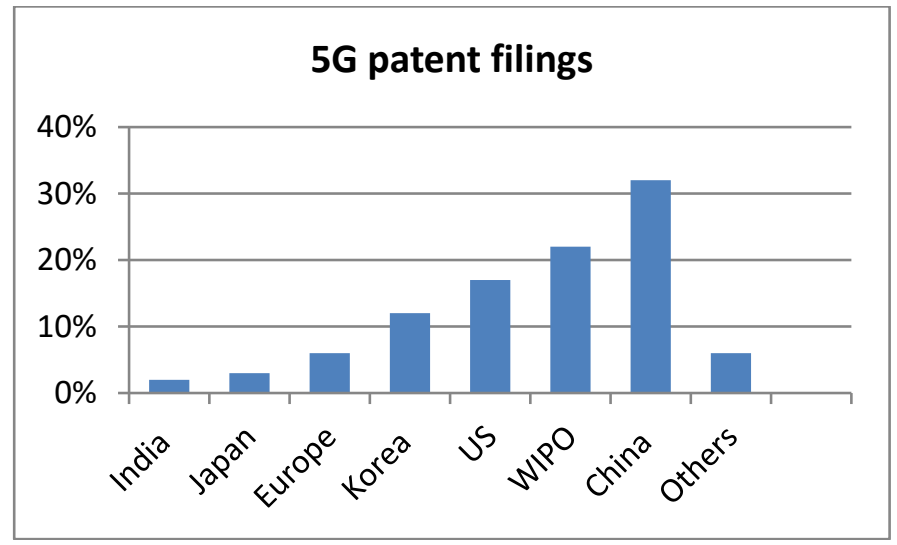

Figure 3: China leads in $5 \mathrm{G}$ patent filings

Applications of $5 G$ :

- Smart Home

- Smart Cities

- Autonomous Driving

- High speed Mobile Network

- Healthcare and mission critical applications

- Internet of Things - Connecting everything

\section{Is $5 G$ really required in India?}

Different countries are investing time, money and resources to bring in $5 \mathrm{G}$ technology as soon as possible which will result in advancement of technology, benefiting every sectors of the country. Though all sectors in India are making the optimum use of $4 \mathrm{G}$ technology also telecom industry are currently not capable of bringing in $5 \mathrm{G}$ technology due to ongoing debts. But, if India will not invest on 5G technology then it will lag behind as compared to other countries. As per the report and statistics, blocking Huawei from rolling out 5G may cause
$\$ 4.7$ bn loss to India by 2035 . [8] China is also making 5G infrastructure development corridor with Pakistan. If there will be early development of $5 \mathrm{~g}$ happen in Pakistan then it will politically affect India. For rural development we need intelligence hardware which will be built on the basis of $5 \mathrm{G}$.

\section{Why $5 g$ is better than $4 g$ ?}

In $4 \mathrm{~g}$, we can connect 10000 people per square kilometer but $5 \mathrm{~g}$ will be able to connect more than 2 million people in one square kilometer.5g can be responsible to make intelligence hardware which can be used In healthcare ,robotics, defense etc. Most important feature that $5 \mathrm{~g}$ can give is remote medical surgery which can be predominantly used in rural area and India has such issue from long time. Second reason china gives full data privacy to India if India will make $5 \mathrm{~g}$ BRI with China.

\section{India and their own take on $5 G$ ?}

The government of India has take one step forward in $5 \mathrm{G}$ development by own self without taking further help from other companies, the project is named as "Indigenous $5 \mathrm{G}$ bed test". The some reputed organization are taking part into this program. These organizations are IIT DELHI, IIT MUMBAI, IIT Chennai, IIT Kanpur, IISC Bengaluru, CEWIT (Centre Of Excellence In Wireless Technology) and SAMEER (Society Of Applied Microwave Electronics Engineering and Research). [9] Jio is the only company giving proposal to government of India to implement 5G technology at mid of this year. Till now there is no $5 \mathrm{G}$ test done by Huwaei in India.

\begin{tabular}{|c|c|c|}
\hline \multicolumn{2}{|c|}{$\begin{array}{l}\text { ZTE is conduction pre- } 5 G \text { trials } \\
\text { with Bharti Airte, Vodafone and } \\
\text { RJio }\end{array}$} & $\begin{array}{l}\text { Will launch telecom } \\
\text { products designed and } \\
\text { customized for the } \\
\text { local needs. }\end{array}$ \\
\hline $\begin{array}{l}\text { Expects India business } \\
\text { to grow faster than its } \\
\text { other global markets }\end{array}$ & \multicolumn{2}{|c|}{$\begin{array}{l}\text { Has tied up with BSNL to } \\
\text { provide network support and } \\
5 \mathrm{G} \text { gear for future network } \\
\text { needs. }\end{array}$} \\
\hline $\begin{array}{l}\text { Recently won a } \\
\text { contract from state-run } \\
\text { BSNL for network } \\
\text { expansion in the north } \\
\text { and east }\end{array}$ & \multicolumn{2}{|c|}{$\begin{array}{l}\text { Testing its } 5 \text { G-ready products } \\
\text { with Airtel and BSNL. } \\
\text { India plans to roll out } 5 \mathrm{G} \\
\text { services for consumers by } 2022\end{array}$} \\
\hline
\end{tabular}

Figure 5: India's another step forward

Indian organizations and their step towards $5 G$ ?

Wipro has tied up with IIT Kharagpur to do research on $5 \mathrm{~g}$.the final outcome from this partnership will be: Wipro can use these technology to provide service to their costumer and IIT Khaaragpur get financial help and some expensive training and knowledge about these emerging technology via industry expert with the help of Wipro. [10] IIT Kanpur and TCS has joined hand for $5 \mathrm{G}$ research.IIT DELHI is doing research on $5 \mathrm{G}$ MIMO ... which will be implemented in next 4 years. It has 32 base stations which will be used to verify and test the algorithms. 
Companies which are predominantly working on $5 G$ ?

- Nokia

- Cisco

- ZTe

- Huwaei

- Qualcom

- Samsung

- Databangteleco,

- Altiostar

Spectrum allocation dilemma in India?

Each government organization of India is demanding certain bands for their work by the result of that there is very less amount of spectrum is remaining for private organization in India which is blocking $5 \mathrm{G}$ to come into India early. [10] DoT has accepted the following spectrum for the given organization; $5 \mathrm{G}$ spectrum range lies between $3.3 \mathrm{ghz}$ to 3.6 Ghz.

\begin{tabular}{|l|l|}
\hline \multicolumn{1}{|c|}{ ORGANISATION } & \multicolumn{1}{|c|}{ SPECTRUM ALLOCATED } \\
\hline ISRO & $3400-3425 \mathrm{MHz}$ \\
\hline DEFENCE SERVICE & $3300-3400 \mathrm{MHZ}(\mathrm{NEARLY}$ \\
& $100 \mathrm{MHZ})$ \\
\hline 5G SERVICES(COMMERCIAL) & $175 \mathrm{GHZ}$ \\
\hline
\end{tabular}

Table 3: Allocated Spectrum for various use

\section{CONCLUSION}

5G will provide the elementary infrastructure for building smart cities, which will enhance the mobile network performance and capabilities to their maxima. Lot of improvements is done from $1 \mathrm{G}$ to $5 \mathrm{G}$. $5 \mathrm{G}$ is expected to be released by the end of 2022. The government had initially stated that India could implement initial $5 \mathrm{G}$ roll outs by the end of 2021 and is expected to hold auctions for airwaves to facilitate the next generation technology by the end of fiscal year through March 2021. One of the most famous quotes said about $5 \mathrm{G}$ is: $5 \mathrm{G}$ is an emerging technology that hasn't really been defined yet.

\section{REFERENCES}

[1] Mrs. Sandhya Shinde, Amruta Nikam, Swati Joshi, "An Overview of 5G Technology," International Research Journal of Engineering and Technology (IRJET), Volume: 03 Issue: 04 (April-2016)

[2] Manjurul H. Khan, P.C. Barman, "5G- FUTURE GENERATION TECHNOLOGIES OF WIRELESS COMMUNICATION "REVOLUTION 2020," American Journal of Engineering Research (AJER), Volume-4, Issue-5, 2015

[3] Ms. Reshma S. Sapakal, Ms. Sonali S. Kadam, "5G Mobile Technology," International Journal of Advanced Research in Computer Engineering \& Technology (IJARCET), Volume 2, Issue 2, February 2013

[4] Haard Mehta, Darpit Patel, Bhaumik Joshi, Hardik Modi, "5G Technology of Mobile Communication: A Survey", International Conference on Intelligent Systems and Signal Processing (ISSP), Conference Paper, March 2013

[5] "Functional Architecture for 5G Mobile Networks" by Aleksandar Tudzarov and Toni Janevski published in International Journal of Advanced Science and Technology Vol. 32, July, 2011

[6] Gohil, Asvin, Hardik Modi, and Shobhit K. Patel. "5G technology of mobile communication: A survey." 2013 international conference on intelligent systems and signal processing (ISSP). IEEE, 2013.

[7] http://image.slidesharecdn.com/telecomseminar150818145637-lva1app6891/95/telecom-seminar-0g5g-eng-hasan-shamroukh-32638.jpg? $\mathrm{cb}=1439909885$

[8] http://itinfozone.com/wpcontent/uploads/2018/08/1g-2g-3g-4g-5g660x291.png

[9] https://economictimes.indiatimes.com/industry/telecom/telecomnews/5g-subscription-in-india-to-become-available-in-2022ericsson/articleshow/72228074.cms?from $=\mathrm{mdr}$

[10] https://economictimes.indiatimes.com/industry/telecom/telecomnews/telcos-to-defer-5g-rollout-for-5-years-as-prices-toohigh/articleshow/72233242.cms 